\title{
PERBEDAAN PENERIMAAN TEMAN SEBAYA ANTARA SISWA YANG \\ BERKEPRIBADIAN EKSTROVERT DAN INTROVERT PADA SISWA \\ SMK NEGERI 1 MADIUN TAHUN PELAJARAN 2010/2011
}

Noviyanti Kartika Dewi

\begin{abstract}
Abstrak
Penelitian ini bertujuan untuk mengetahui gambaran penerimaan teman sebaya pada siswa yang berkepribadian ekstrovert dan yang berkepribadian introvert. Penelitian ini juga ingin mengetahui perbedaan penerimaan teman sebaya antara siswa yang berkepribadian ekstrovert dan yang berkepribadian introvert

Rancangan penelitian yang digunakan adalah deskriptif dan komparatif. Populasi dalam penelitian ini adalah siswa kelas X SMK Negeri 1 Madiun, sebesar 735 siswa. Teknik sampel yang digunakan dalam penelitian ini adalah Cluster smapling. Pengambilan sampel dalam penelitian ini sebesar 33\%, sehingga sampel dalam penelitian ini sebesar 242 siswa. Analisis data dalam penelitian ini menggunakan analisis deskriptif dan analisis komparatif.

Hasil penelitian menunjukkan bahwa terdapat siswa yang berkepribadian ekstrovert $(54,1 \%)$ lebih banyak daripada siswa yang berkepribadian introvert $(45,9 \%)$. Penerimaan teman sebaya pada siswa yang berkepribadian ekstrovert berada pada kategori kurang $(49,6 \%)$ sedangkan peneimaan teman sebaya pada siswa yang berkepribadian introvert berada pada kategori kurang (44,2\%). Berdasarkan nilai persentase tersebut terdapat perbedaan penerimaan teman sebaya antara siswa yang berkepribadian ekstrovert dan introvert. Berdasarkan hasil uji-t yang dilakukan diperoleh hasil nilai $\mathrm{p}(0,000)<\alpha(0,05)$ maka dapat dinyatakan terdapat perbedaan penerimaan teman sebaya antara siswa yang berkeribadian ekstrovert dan siswa yang berkepribadian introvert.
\end{abstract}

Kata Kunci: penerimaan teman sebaya, ekstrovert, introvert

\section{Pendahuluan}

Masa remaja merupakan salah satu fase kehidupan yang harus dilewati setiap manusia. Masa remaja mempunyai tempat yang istimewa dihati setiap individu. Masa ini sering menjadi masa yang tak terlupakan bagi setiap individu, banyak hal yang terjadi baik peristiwa menyenangkan atau menyedihkan. Menurut Konopka (dalam Yusuf, 2001) masa remaja merupakan periode kehidupan yang penting dalam siklus perkembangan individu. 
Perkembangan pada masa remaja ini akan menentukan perkembangan individu tersebut pada masa selanjutnya. Salah satu perkembangan yang paling menonjol pada masa remaja adalah perkembangan sosialnya, khususnya yang berhubungan dengan teman sebaya. Hal ini terjadi karena pada masa ini remaja sudah mengenal adanya kepentingan dan kebutuhan yang sama dengan teman sebayanya.

Penerimaan kelompok terhadap diri remaja serta rasa ikut serta dalam kelompok akan memperkuat penilaian diri yang positif pada remaja (Mappiare, 1982). Sehingga terpenuhi atau tidaknya kebutuhan remaja akan penerimaan teman sebaya akan berpengaruh pada kehidupan sosiopsikologisnya dan perkembangannya pada masa selanjutnya. Adapun salah satu faktor yang mempegaruhi penerimaan adalah faktor kepribadian. Setiap orang mempunyai kepribadian yang berbeda-beda. Jung mengelompokkan kepribadian menjadi dua yaitu kepribadian ekstrovert dan kepribadian introvert.

Kepribadian ekstrovert mempunyai ciri-ciri suka bergaul dengan orang lain, berorientasi pada lingkungan, terbuka, tidak banyak pertimbangan dan aktif. Sedangkan kepribadian introvert mempunyai ciri-ciri tidak suka bergaul, berorientasi pada diri sendiri, tertutup, banyak pertimbangan dan pasif.

Diterima atau tidaknya remaja oleh teman sebayanya tergantung dari kepribadian yang ia miliki. Hal ini seperti yang diungkapkan oleh Rogers (1977) bahwa keberhasilan seseorang dalam menyesuaiakan diri dengan lingkungannya tergantung pada tingkat kepribadian ekstrovert dan introvert yang ia miliki. Hal ini berarti diterima atau tidaknya remaja oleh teman sebayanya tergantung pada kepribadian yang ia miliki. 
Sebagai individu yang khas dan unik, remaja memiliki kepribadian yang berbeda-beda. Perbedaan tersebut akan mempengaruhi pola sikap dan perilakunya (Fatimah, 2006: 30). Salah satu pola sikap dan perilaku tersebut berkaitan dengan penerimaan terhadap teman sebayannya. Sehingga dapat disimpulkan bahwa perbedaan kepribadian yang dimiliki oleh masing-masing remaja akan berpengaruh pada penerimaan teman sebayanya. Berdasarkan uraian di atas penulis ingin meneliti tentang perbedaan penerimaan teman sebaya antara siswa yang berkepribadian ekstrovert dan siswa yang berkepribadian introvert.

Adapun rumusan masalah dalam penelitian ini adalah: (1) bagaimana penerimaan teman sebaya pada siswa yang berkepribadian ekstrovert di SMK Negeri 1 Madiun, (2) bagaimana penerimaan teman sebaya pada siswa yang berkepribadian introvert di SMK Negeri 1 Madiun, (3) apakah ada perbedaan penerimaan teman sebaya antara siswa yang berkepribadian ekstrovert dan introvert di SMK Negeri 1 Madiun.

Tujuan penelitian yang ingin dicapai dalam penelitian ini adalah: (1) untuk mengetahui gambaran penerimaan teman sebaya pada siswa yang mempunyai tipe kepribadian ekstrovert di SMK Negeri 1 Madiun, (2) untuk mengetahui gambaran penerimaan teman sebaya pada siswa yang mempunyai tipe kepribadian introvert di SMK Negeri 1 Madiun, (3) untuk mengetahui perbedaan peneriamaan teman sebaya antara siswa yang berkeribadian ekstrovert dan introvert di SMK Negeri 1 Madiun.

\section{Metode Penelitian}


Penelitian ini menggunakan rancangan penelitian deskriptif dan komparatif. Penelitian deskriptif digunakan untuk mengetahui tipe kepribadian (sebagai variabel bebas) dan penerimaan teman sebaya (sebagai variabel terikat) siswa SMK Negeri 1 Madiun. Sedangkan penelitian komparatif digunakan untuk mengetahui perbedaan penerimaan teman sebaya antara siswa yang berkepribadian ekstrovert dan introvert di SMK Negeri 1 Madiun. Dalam penelitian ini terdapat dua variabel yang akan diteliti, yaitu variabel penerimaan teman sebaya sebagai variabel terikat dan variabel tipe kepribadian sebagai variable bebas.

Populasi dalam penelitian ini adalah siswa X SMK Negeri 1 Madiun. Jumlah populasi sebanyak sebesar 735. Pengambilan sampel dalam penelitian ini dilakukan secara random. Pengambilan besarnya sampel dalam penelitian sebesar $33 \%$. Jadi sampel yang diperlukan dalam penelitian ini sebesar 242 siswa.

Instrumen penelitian yang yang digunakan dalam penelitian ini ada dua yaitu: instrument sosiometri dan instrumen inventori kepribadian. Instrumen sosiometri digunakan untuk mengetahui penerimaan teman sebaya sedangkan instrumen inventori kepribadian digunakan untuk mengetahui tipe kepribadian siswa. Sebelum melakukan penelitian peneliti melakukan uji coba instrument untuk mengetahui tingkat validitas dan reliabilitas instrument yang akan digunakan dalam penelitian.

Dalam penelitian ini peneliti melakukan dua uji coba, yaitu uji ahli dan uji coba instrumen. Untuk instrumen sosiometri peneliti melakukan uji ahli kepada orang yang ahli dalam masalah yang sedang dikaji dalam penelitian ini yaitu bidang praktik teknik non testing. Sedangkan untuk instrumen inventori 
kepibadian peneliti melakukan uji coba kepada siswa kelas X SMK Negeri 1 Madiun. Sebelum analisis dilakukan terlebih dahulu skor yang diperoleh siswa (skor total) dikorelasikan dengan skor item untuk mengetahui validitas instrumen.

Berdasarkan hasil uji validitas yang telah dilakukan diperoleh hasil sebagai berikut, untuk item favorable yang valid 15 aitem dan yang gugur 11 item. Sedangkan untuk item unfavorable yang valid 15 aitem dan yang gugur 11 item. Sehingga item yang valid sebannyak 30 item dan yang tidak valid atau gugur 22 item. Item yang valid digunakan dalam penelitian sedangkan yang tidak valid dibuang atau tidak dipakai dalam penelitian. Berdasarkan hasil pengukuran reliabilitas inventori kepribadian dengan menggunakan rumus Alpha Cronbach dibantu dengan SPSS 14 for windows diperoleh hasil reliabilitas sebesar 0,898 yang berarti inventori kepribadian ini memiliki tingkat reliabilitas yang tinggi dan memuaskan.

Kegiatan analisis data merupakan suatu proses pengolahan data terhadap data yang telah terkumpul saat pengumpulan data. Analisis data dilakukan dalam penelitian ini bertujuan untuk menjawab perbedaan penerimaan teman sebaya antara siswa bertipe kepribadian ekstrovert dan introvert. Dalam kegiatan ini beberapa langkah yang perlu diperhatikan yaitu pemberian skor, tabulasi skor dan teknik analisis data.

\section{Hasil Penelitian}

Hasil pengolahan dan pengujian data menunjukkan bahwa siswa X SMK Negeri 1 Madiun yang mempunyai kepribadian ekstrovert persentasenya sebesar $54,1 \%$ dengan interpretasi banyak sedangkan untuk siswa yang bertipe kepribadian introvert persentasenya sebesar $45,9 \%$ dengan interpretasi cukup 
banyak. Berdasarkan persentase tersebut diketahui bahwa siswa kelas X SMK

Negeri 1 Madiun lebih banyak yang berkepribadian ekstrovert daripada introvert.

\section{Hasil analisis deskripsi penerimaan teman sebaya pada siswa yang} berkepribadian ekstrovert adalah sebagai berikut:

Penerimaan teman sebaya pada siswa yang berkepribadian ekstrovert dibedakan menjadi dua variabel yaitu variable penerimaan teman sebaya dalam kelompok belajar dan penerimaan teman sebaya dalam kelompok pergaulan. Berdasarkan analisis yang dilakukan dapat diketahui bahwa penerimaan teman sebaya dalam kelompok belajar pada siswa yang berkepribadian ekstrovert berada dalam klasifikasi kurang (K) sebesar $(45,1 \%)$. Sedangkan penerimaan teman sebaya dalam kelompok pergaulan pada siswa yang berkepribadian ekstrovert berada dalam klasifikasi cukup (C) sebesar $(39,8)$. Berdasarkan hasil persentase tersebut dapat disimpulkan bahwa penerimaan siswa yang berkepribadian ekstrovert dalam kelompok belajar kurang baik sedangkan penerimaan dalam kelompok pergaulan cukup baik.

Secara keseluruhan tingkat penerimaan teman sebaya pada siswa yang berkepribadian ekstrovert berada pada klasifikasi kurang (K) sebesar $(49,6 \%)$. Hal ini dilihat dari nilai persentase yang tinggi pada interpretasi kurang $(\mathrm{K})$ dibandingkan dengan nilai persentase pada interpretasi yang lainnya. Sehingga dapat disimpulkan bahwa penerimaan teman sebaya pada siswa yang berkepribadian ektrovert adalah kurang baik. Untuk lebih jelasnya dapat dilihat pada tebel 1.1 dan 1.2

Tabel 1.1 Penerimaan teman sebaya dalam kelompok belajar dan pergaulan pada siswa yang berkepribadian ekstrovert 


\begin{tabular}{|c|c|c|c|c|}
\hline No & Tingkat penerimaan teman sebaya & $\mathbf{f}$ & $\%$ & Interpretasi \\
\hline \multirow[t]{6}{*}{$\mathbf{1}$} & $\begin{array}{l}\text { Penerimaan teman sebaya dalam kelompok } \\
\text { belajar }\end{array}$ & & & \\
\hline & Baik Sekali (BS) & 2 & 1,5 & Sedikit sekali \\
\hline & Baik (B) & 10 & 7,5 & Sedikit sekali \\
\hline & Cukup (C) & 33 & 24,8 & Sedikit \\
\hline & Kurang (K) & 60 & 45,1 & Cukup banyak \\
\hline & Sangat Kurang (SK) & 27 & 21,1 & Sedikit \\
\hline \multirow[t]{6}{*}{2} & $\begin{array}{l}\text { Penerimaan teman sebaya dalam kelompok } \\
\text { pergaulan }\end{array}$ & & & \\
\hline & Baik Sekali (BS) & 3 & 2,2 & Sedikit sekali \\
\hline & Baik (B) & 22 & 16,5 & Sedikit sekali \\
\hline & Cukup (C) & 53 & 39,8 & Sedikit \\
\hline & Kurang (K) & 43 & 32,3 & Sedikit \\
\hline & Sangat Kurang (SK) & 12 & 9,0 & Sedikit sekali \\
\hline
\end{tabular}

Tabel 1.2 Penerimaan teman sebaya pada siswa yang berkepribadian ekstrovert

\begin{tabular}{|l|l|l|l|}
\hline $\begin{array}{l}\text { Tingkat penerimaan teman } \\
\text { sebaya }\end{array}$ & $\mathbf{f}$ & $\mathbf{\%}$ & Interpretasi \\
\hline Baik Sekali (BS) & 3 & 2,3 & Sedikit sekali \\
\hline Baik (B) & 9 & 6,8 & Sedikit sekali \\
\hline Cukup (C) & 36 & 27,1 & Sedikit \\
\hline Kurang (K) & 66 & 49,6 & Cukup banyak \\
\hline Sangat Kurang (SK) & 19 & 14,3 & Sedikit sekali \\
\hline
\end{tabular}

2. Hasil analisis deskripsi sosiometri penerimaan teman sebaya pada siswa yang berkepribadian introvert 
Penerimaan teman sebaya pada siswa yang berkepribadian introvert dibedakan menjadi dua variabel yaitu variabel penerimaan teman sebaya dalam kelompok belajar dan penerimaan teman sebaya dalam kelompok pergaulan. Berdasarkan analisi yang dilakukan dapat diketahui bahwa penerimaan teman sebaya dalam kelompok belajar pada siswa yang berkepribadian introvert berada dalam klasifikasi sangat kurang (SK) sebesar $(49,6 \%)$. Sedangkan penerimaan teman sebaya dalam kelompok pergaulan pada siswa yang berkepribadian introvert berada dalam klasifikasi kurang $(\mathrm{K})$ sebesar $(46,9 \%)$. Berdasarkan hasil persentase tersebut dapat disimpulkan bahwa penerimaan teman sebaya dalam kelompok belajar pada siswa yang berkepribadian introvert sangat kurang sedangkan penerimaan teman sebaya dalam kelompok pergaulan kurang.

Secara keseluruhan tingkat penerimaan teman sebaya pada siswa yang berkepribadian introvert adalah berada pada klasifikasi kurang (K) sebesar (44,2\%). Hal ini dilihat dani nilai persentase yang tinggi pada interpretasi kurang $(\mathrm{K})$ dibandingkan dengan nilai persentase pada interpretasi yang lainnya. Sehingga dapat disimpulkan bahwa penerimaan teman sebaya pada siswa yang berkepribadian introvert adalah kurang baik. Untuk lebih jelasnya dapat dilihat pada tabel 1.3 dan 1.4.

Tabel 1.3 Penerimaan teman sebaya dalam kelompok belajar dan pergaulan pada siswa yang berkepribadian introvert 


\begin{tabular}{|l|l|l|l|l|}
\hline No & Tingkat penerimaan teman sebaya & f & $\%$ & Interpretasi \\
\hline 1 & $\begin{array}{l}\text { Penerimaan teman sebaya dalam kelompok } \\
\text { belajar }\end{array}$ & & & \\
\cline { 2 - 5 } & Baik Sekali (BS) & 3 & 2,7 & Sedikit sekali \\
\cline { 2 - 6 } & Baik (B) & 4 & 3,5 & Sedikit sekali \\
\cline { 2 - 6 } & Cukup (C) & 8 & 7,1 & Sedikit sekali \\
\cline { 2 - 6 } & Kurang (K) & 43 & 37,2 & Sedikit \\
\cline { 2 - 6 } & Sangat Kurang (SK) & 55 & 49,6 & Cukup banyak \\
\hline \multirow{4}{*}{$\begin{array}{l}\text { Penerimaan teman sebaya dalam kelompok } \\
\text { pergaulan }\end{array}$} & & & \\
\cline { 2 - 6 } & Baik Sekali (BS) & 2 & 1,8 & Sedikit sekali \\
\cline { 2 - 6 } & Baik (B) & 11 & 12,4 & Sedikit sekali \\
\cline { 2 - 6 } & Cukup (C) & 24 & 18,6 & Sedikit Sekali \\
\cline { 2 - 6 } & Kurang (K) & 23 & 20,4 & sedikit \\
\cline { 2 - 5 } & Sangat Kurang (SK) & & & Cukup banyak \\
\hline
\end{tabular}

Tabel 1.4 Penerimaan teman sebaya pada siswa yang berkepribadian Introvert

\begin{tabular}{|l|l|l|l|}
\hline Tingkat penerimaan teman sebaya & $\mathbf{f}$ & $\mathbf{\%}$ & Interpretasi \\
\hline Baik Sekali (BS) & 2 & 1,8 & Sedikit sekali \\
\hline Baik (B) & 2 & 1,8 & Sedikit sekali \\
\hline Cukup (C) & 14 & 12,4 & Sedikit sekali \\
\hline Kurang (K) & 50 & 44,2 & Cukup banyak \\
\hline Sangat Kurang (SK) & 45 & 39,8 & Sedikit \\
\hline
\end{tabular}




\section{Hasil analisis deskripsi perbedaan penerimaan teman sebaya antara siswa yang berkepribadian ekstrovert dan siswa yang berkepribadian introvert}

Berdasarkan analisis yang telah dilakukan, dapat disimpulkan bahwa terdapat perbedaan penerimaan teman sebaya antara siswa yang berkepribadian ekstrovert dan siswa yang berkepribadian introvert. Hal ini dapat diketahui dari penerimaan teman sebaya pada siswa yang berkepribadian ekstrovert berada pada klasifikasi kurang (K) dengan persentase sebesar (49,6\%). Sedangkan penerimaan siswa yang berkepribadian introvert berada pada klasifikasi kurang (K) dengan persentase sebesar $(44,2 \%)$. Berdasarkan analisis tersebut diketahui bahwa penerimaan teman sebaya antara siswa yang berkepribadian ekstrovert dan siswa yang berkepribadian introvert sama-sama berada pada klasifikasi kurang (K). Namun jika dilihat dari nilai persentasenya maka akan terlihat perbedaan penerimaan teman sebaya pada siswa yang berkepribadian ekstrovert dan introvert.

Adanya perbedaan penerimaan teman sebaya antara siswa yang berkepribadian ekstrovert dan introvert ini akan dibuktikan dengan melakukan Uji-t. Berdasarkan hasil Uji-t yang dilakukan untuk mengetahui apakah ada perbedaan penerimaan teman sebaya yang signifikan antara siswa yang berkepribadian ekstrovert dan introvert.

Berdasarkan hasil Uji-t yang telah dilakukan diperoleh hasil bahwa ada perbedaan yang signifikan antara penerimaan teman sebaya yang berkepribadian ekstrovert dan introvert. Taraf signifikasi yang digunakan dalam penelitian ini adalah 0,05 , sehingga dinyatakan terdapat perbedaan 
apabila nilai signifakasi penelitian lebih kecil dari taraf signifikasi yang ditetapkan yaitu 0,05. Dalam Uji-t diatas nilai signifikasi penelitian 0,000. Sehingga dapat disimpulkan bahwa dalam penelitian ini terdapat perbedaan penerimaan teman sebaya antara siswa yang berkepribadain ekstrovert dan introvert.

\section{Pembahasan}

Pembahasan hasil penelitian yang terdiri dari pembahsan penerimaan teman sebaya pada siswa yang berkepribadian ekstrovert dan siswa yang berkepribadian introvert serta pembahasan mengenai perbedaan penerimaan teman sebaya antara siswa yang berkepribadian ekstrovert dan introvert.

\section{A. Penerimaan Teman Sebaya pada Siswa yang Berkepribadian Ekstrovert}

Berdasarkan hasil penelitian diperoleh hasil bahwa siswa kelas X SMK Negeri 1 Madiun yang memiliki kecenderungan kepribadian ekstrovert. Penelitian terhadap penerimaan teman sebaya pada siswa yang berkepribadian ekstrovert dalam penelitian ini dibedakan menjadi dua variabel yaitu penerimaan teman sebaya dalam kelompok belajar dan penerimaan teman sebaya dalam kelompok pergaulan. Hasil penelitian menunjukkan bahwa penerimaan teman sebaya dalam kelompok belajar pada siswa yang berkepribadian ekastrovert adalah kurang baik sedangkan penerimaan teman sebaya dalam kelompok pergaulan cukup baik.

Berdasarkan hasil penelitian tesebut maka siswa yang berkepribadian ekstrovert mendapatkan penerimaan yang baik pada kelompok pergaulan . Hal ini sesuai dengan ciri kepribadian yang ada pada diri siswa yang berkepribadian ekatrovert. Menurut Jung ciri kepribadian ekstrovert adalah mudah bergaul, 
hatinya terbuka dan hubungan dengan orang lain lancar (Suryabrata, 2002: 162). Teori tersebut sesuai dengan hasil penelitian dimana anak yang berkepribadian ektrovert mendapat penerimaan yang cukup baik dari teman sebayanya.

Sedangkan hasil penelitian penerimaan teman sebaya dalam kelompok belajar pada siswa yang berkepribadian ekatrovert mendapatkan penerimaan kurang baik dari teman sebayanya. Selain memiliki ciri mudah bergaul dengan orang lain remaja yang mempunyai kepribadian ekstrovert juga mempunyai ciri mudah bosan, kurang bisa berkonsentrasi dalam waktu lama dan mudah berubahubah emosinya (http://edu4all-abidinitov.blogspot.com). Ciri-ciri mudah bosan, kurang bisa berkonsentrasi dalam waktu lama dan mudah berubah-ubah emosinya tersebut dalam kelompok belajar kurang bisa diterima. Sehingga anak yang mempunyai kepribadian ekstrovert mendapatkan penerimaan yang kurang dari kelompok belajar teman sebayanya.

Berdasarkan hasil akumulasi dari penerimaan dalam kelompok belajar dan kelompok pergaulan maka hasil penelitian penerimaan teman sebaya pada siswa yang berkepribadian ekstrovet menunjukkan bahwa penerimaan teman sebaya pada siswa yang berkepribadian ekstrovert berada pada tingkat kurang baik. Hal ini terjadi karena adanya kelompok-kelompok atau geng, sehingga pemilihan terhadap teman yang disukai terpusat hanya pada kelompoknya saja. Mereka tidak akan memilih teman diluar kelompoknya, karena ia merasa terikat dengan kelompok tersebut.

\section{B. Penerimaan Teman Sebaya pada Siswa yang Berkepribadian Introvert}

Penerimaan teman sebaya merupakan suatu kebutuhan bagi remaja. Oleh sebab itu remaja akan berusaha untuk menjalin hubungan yang baik dengan teman 
sebayannya. Akan tetapi dalam menjalin hubungan tersebut tidak semuanya berjalan dengan lancar atau sesuai harapan remaja. Ada remaja yang diterima oleh teman sebayannya namun ada pula remaja yang ditolak oleh teman sebayanya. Salah satu faktor yang mempengaruhi diterima atau ditolaknya seorang remaja oleh teman sebayannya adalah kepribadian remaja tersebut. Seperti diketahui bahwa kepribadian dibedakan menjadi dua yaitu kepribadian ekstrovert dan introvert. Berdasarkan hasil penelitian, remaja yang mempunyai kepribadian ekstrovert memperoleh penerimaan yang kurang baik dari teman sebayanya. Lalu bagaimana dengan siswa yang berkepribadian introvert?.

Berdasarkan hasil penelitian yang dilakukan pada siswa kelas X SMK Negeri 1 Madiun diperoleh hasil bahwa siswa yang mempunyai kepribadian introvert sebanyak $113(45,9 \%)$ dengan klasifikasi cukup banyak. Sehingga siswa yang memiliki kepribadian introvert lebih sedikit dibandingkan siswa yang mempunyai kepribadian ekstrovert. Seperti pada kelompok ekstrovert sebelumnya, penerimaan teman sebaya pada kelompok introvert juga dibagi menjadi dua variabel yaitu penerimaan teman sebaya dalam kelompok belajar dan penerimaan teman sebaya dalam kelompok bergaul.

Hasil penelitian menunjukkan bahwa penerimaan teman sebaya introvert pada kelompok belajar adalah sangat kurang baik. Sedangkan penerimaan teman sebaya kelompok pergaulan adalah kurang baik. Jika kedua penerimaan (penerimaan dalam kelompok belajar dan pergaulan) digabungkan maka diketahui bahwa penerimaan teman sebaya pada siswa yang berkepribadian introvert adalah kurang baik. Berdasarkan hasil penelitian tersebut dapat disimpulkan bahwa 
penerimaan teman sebaya pada siswa yang berkepribadian introvert berada pada tingkat yang kurang baik.

Kurang baiknya penerimaan yang diterima siswa yang berkepribadian introvert dikarenakan ciri kepribadiannya yang cenderung tertutup dan sukar bergaul dengan orang lain. Karena kurang baiknya penyesuaian diri dengan dunia luar dan sukar bergaul dengan orang lain maka anak yang mempunyai kepribadian introvert mendapatkan penerimaan yang kurang baik dari teman sebayannya.

Kurang diterimannya siswa yang berkepribadian introvert dalam kelompok belajar dan pergaulan akan memberikan dampak sosiopsikologis yang tidak baik pada perkembangan remaja selanjutnya. Hal ini karena remaja dengan kepribadian introvert cenderung tidak tahan sakit, sehingga apabila ia mendapatkan pengalaman yang buruk maka ia akan selalu mengingatnya dan hal ini akan berdampak pada perilaku pergaulan dan prestasi belajarnya di sekolah (http://edu4all-abidinitov.blogspot.com). Masalah ini menjadi pekerjaan rumah bagi pendidik untuk memberikan bimbingan agar anak yang mempunyai kepribadian introvert dapat berkembang dan mencapai perkembangan yang optimal.

\section{Perbedaan Penerimaan Teman Sebaya Antara Siswa Yang Berkepribadian Ekstrovert dan Siswa Yang Berkepribadian Introvert}

Penerimaan teman sebaya merupakan dipilihnya seorang remaja oleh teman-teman seusianya untuk masuk dalam suatu kelompok baik dalam kelompok belajar atau kelompok pergaulan. Menurut Hurlock (1993) penerimaan oleh teman sebaya merupakan salah satu aspek yang mendapat perhatian besar dalam kehidupan sosial remaja, bahkan penerimaan ini dijadikan standar indeks 
keberhasilan sosial seseorang. Dengan demikian penerimaan oleh teman sebaya mempunyai arti yang sangat penting bagi perkembangan kehidupan remaja.

Dalam menjalin interaksi dengan teman sebayanya, tidak semua remaja akan mengalami penerimaan yang baik dari teman sebayanya. Ada pula remaja yang akan menerima penolakan dari teman sebayannya. Yang menjadi pertanyaan, apa yang menyebabkan remaja tersebut diterima atau ditolak oleh teman sebayannya?

Adapun salah satu faktor yang mempengaruhi diterimannya seorang remaja oleh teman sebayanya adalah kepribadian yang dimiliki remaja tersebut. Berdasarkan penelitian yang dilakukan oleh Arifati (2000) menyatakan bahwa faktor kepribadian juga berpengaruh terhadap penerimaan teman sebaya. Hurlock (1980) juga berpendapat bahwa kepribadian merupakan salah satu faktor yang menyebabkan remaja diterima oleh teman sebayanya. Sehingga dapat disimpulkan bahwa kepribadian memainkan peran yang penting dalam penerimaan teman sebaya pada masa remaja.

Kepribadian sendiri dibedakan menjadi dua yaitu kepribadian ekstrovert dan kepribadian introvert. Remaja dengan kepribadian ekstrovert mempunyai ciri-ciri mudah bergaul, hatinya terbuka dan hubungan dengan orang lain lancar sedangkan remaja yang berkepribadian introvert mempunyai ciri-ciri penyesuaian diri dengan dunia luar kurang baik, jiwanya tertutup, sukar bergaul, sukar berhubungan dengan orang lain dan kurang dapat menarik perhatian orang lain.

Kondisi kepribadian remaja yang berbeda-beda menyebabkan perbedaan dalam menerima teman sebaya. Menurut Fatimah (2006: 30) kepribadian seseorang akan mempengaruhi pola sikap dan perilakunya. Salah satu pola sikap dan perilaku yang dipengaruhi oleh kepribadian adalah dalam penerimaan teman sebaya. 
Sehingga perbedaan kepribadian yang dimiliki oleh setiap remaja akan mempengaruhi penerimaan remaja dalam memilih teman sebaya sehingga ada perbedaan penerimaan anatara siswa yang ekstrovert dan introvert.

Berdasarkan hasil penelitian yang dilakukan peneliti, menunjukkan bahwa terdapat perbedaan penerimaan teman sebaya pada siswa yang berkepribadian ekstrovert dan introvert. Hal ini diketahui dari hasil analisis uji-t yang menunjukkan bahwa ada perbedaan yang signifikan dalam penerimaan teman sebaya antara siswa yang berkepribadian ekatrovert dan siswa yang berkepribadian introvert pada siswa kelas X SMK Negeri 1 Madiun.

Hasil penelitian menunjukkan bahwa penerimaan teman sebaya pada siswa yang memiliki kepribadian ekstrovert dan introvert sama-sama berada pada klasifikasi kurang baik. Hal ini merupakan suatu fenomena baru yang ditemukan oleh peneliti. Berdasarkan hasil penelitian tersebut siswa yang mempunyai kepribadian ekstrovert cukup diterima oleh teman sebayanya dalam kelompok pergaulan sedangkan dalam kelompok belajar ia kurang diterima oleh teman sebayanya. Sedangkan siswa yang mempunyai kepribadian introvert mendapat penerimaan yang kurang oleh teman sebayanya dalam kelompok belajar dan mendapatkan penerimaan sangat kurang dari kelompok pergaulan.

Cukup baiknya penerimaan teman sebaya pada siswa yang berkepribadian ekstrovert dan kurang diterimannya siswa yang berkepribadian introvert dalam kelompok pergaulan ini sesuai dengan teori yang dikemukakan oleh Hurlock (1980) yang menyatakan bahwa kondisi yang menyebabkan remaja diterima oleh kelompok teman sebaya salah satunya adalah sifat kepribadian yang menimbulkan penyesuaian sosial yang baik dan sifat ekstrovert. Hal ini bertolak belakang 
dengan penerimaan teman sebaya pada siswa yang bekepribadian ekstrovert dan introvert dalam kelompok belajar. Dimana pada siswa yang berkepribadian ekstrovert mendapatkan penerimaan yang kurang sedangkan siswa yang berkepribadian introvert mendapatkan penerimaan yang sangat kurang dari teman sebayanya. Hasil temuan dalam penelitian ini tentunya sangat memprihatinkan bagi dunia pendidikan. Karena tidak diterimannya remaja oleh teman sebaya akan berpengaruh pada perkembangan sosial dan psikologisnya.

Berdasarkan hasil penelitian yang dilakukan peneliti siswa mendapatkan penerimaan yang kurang baik pada kelompok belajar, hal ini tentunya akan berpengaruh terhadap prestasi belajarnya di sekolah. Hal ini perlu menjadi perhatian yang serius oleh pihak sekolah terutama konselor. Konselor perlu mengatahui mengapa siswa-siswa tersebut baik yang berkepribadian ekstrovert atau introvert kurang mendapatkan penerimaan dari kelompok belajar teman sebayanya. Setelah mengetahui apa penyebabnya maka siswa tersebut perlu diberikan bimbingan pribadi,belajar dan sosial. Sehingga siswa dapat melaksanakan tugas-tugas perkembangannya dan dapat mencapai perkembangan yang optimal.

\section{Kesimpulan dan Saran}

Berdasarkan hasil penelitian yang membahas tentang perbedaan penerimaan teman sebaya antara siswa yang berkepribadian ekstrovert dan introvert maka dapat ditarik kesimpulan sebagai berikut

1. Siswa kelas X SMK Negeri 1 Madiun yang mempunyai kepribadian ekstrovert lebih banyak daripada siswa yang mempunyai kepribadian introvert. 
2. Penerimaan teman sebaya pada siswa yang berkepribadian ekstrovert adalah berada dalam kategori kurang baik.

3. Penerimaan teman sebaya pada siswa yang berkepribadian introvert adalah berada dalam kategori kurang baik.

4. Dari hasil analisis diperoleh kesimpulan bahwa terdapat perbedaan penerimaan teman sebaya antara siswa yang berkepribadian ekstrovert dan introvert.

\section{Saran}

1. Penelitian ini diharapkan dapat memberikan masukan kepada kepala sekolah tentang bentuk kepribadian siswa yang ekstrovert dan introvert serta pengaruhnya terhadap pergaulan siswa, khususnya yang berhubungan dengan penerimaan teman sebaya. Hal ini bisa dijadikan pertimbangan oleh pihak sekolah dalam merancang layanan pribadi dan sosial yang akan diberikan kepada siswa.

2. Penelitian ini diharakan dapat dijadikan sebagai bahan referensi oleh konselor dalam memahami dunia remaja khususnya yang berhubungan dengan teman sebaya dan faktor-faktor yang mempengaruhi penerimaan teman sebaya. Secara umum siswa yang berkepribadian ektrovert mendapatkan penerimaan lebih baik dari pada siswa yang berkepribadian introvert. Hal ini menjadi pekerjaan rumah untuk konselor dalam membantu siswa yang mempunyai kepribadian introvert agar ia bisa diterima oleh teman-teman sebayannya. Dan supaya siswa tersebut dapat mencapai perkembangannya secara optimal. Oleh sebab itu penelitian ini diharapkan dapat membantu atau memeberikan masukan kepada konselor dalam menyusun layanan bimbingan sosial, pribadi dan belajar kepada siswa. 
3. Dari hasil penelitian yang telah dilakukan peneliti diharapkan kepada peneliti selanjutnya dapat mengadakan penelitian lebih lanjut mengenai penerimaan teman sebaya, faktor-faktor yang mempengaruhi dan topik-topik lain yang terkait dengan penerimaan teman sebaya

\section{Daftar Pustaka}

Abu Ahmadi . 1997. Ilmu Sosial Dasar. Jakarta: Renika Cipta.

Alwisol. 2006. Psikologi kepribadian. Malang: UMM Press.

Andi Mappiare. 1982. Psikologi Remaja. Surabaya: Usaha Nasional.

Atkinson, Rita L dan Richard C Atkinson. 1999. Pengantar Psikologi. (edisi kedelapan jilid dua, alih bahasa Nurdjannah Taufiq). Jakarta: Erlangga

Bimo Walgito. 2003. Psikologi Sosial. Suatu Pengantar. Yogyakarta: Andi.

Boeree, George. 2004. Personality Theories. Melacak Kepribadian Anda Bersama Psikologi Dunia. Jogjakarta: Prismasophie.

Dimyati Mahmud. 1989. Psikologi Pendidikan. Departemen Pendidikan dan Kebudayaan Direktorat Jendral Pendidikan Tertinggi Proyek Pengembangan Lembaga Pendidikan Tenaga Kependidikan. Jakarta.

E. Koeswara. 1991. Teori-Teori Kepribadian. Bandung: PT Eresco.

Gina Ariestya Ningrum. 2006. Hubungan Tipe Kepribadian dan Penyesuaian Sosial Mahasiswa Indekost. (skripsi tidak diterbitkan). Malang.

Hurlock, Elizabeth B. 1980. Psikologi Perkembangan Suatu Pendekatan Sepanjang Rentang Kehidupan. Jakarta: Erlangga.

Hurlock, Elizabeth B. 1993. Perkembangan Anak Jilid 1,2. Jakarta: Erlangga.

Kartini Kartono. 2000. Psikologi Umum.Jakarta: Rineka Cipta.

Muhammad Al-Mighwar. 2006. Psikologi Remaja Petunjuk Bagi Guru dan Orang Tua. Bandung: Pustaka Setia.

Nur Hidayah,. 1998. Pemahaman Individu: Teknik Non Tes. Malang. Fakultas Pertanian Universitas Brawijaya. 
Nur Hidayah \& Indreswari, Henny. 1991. Teknik Pemahaman Individu Non Tes. Departemen Pendidikan dan Kebudayaan Institut Keguruan dan Ilmu Pendidikan Malang Proyek Operasi dan Perawatan Fasilitas.

Saifuddin Azwar, 2003. Penyusunan Skala Psikologi. Yogyakarta: Pustaka Pelajar.

Santrock, John W. 2002. Life Span Development. Perkembangan Masa Hidup. (edisi kelima jilid dua, alih bahasa Juda Damanik dan Achmad Chusairi). Jakarta: Erlangga.

Sarlito Wirawan Sarwono. 2006. Psikologi Remaja. Jakarta: PT Raja Grafindo Persada.

S. Gunarsa \& Yulia, G. 1986. Psikologi Perkembangan. Jakarta: BPK Gunung Kelud.

Shulhu Huzaimah Akram . 2007. Hubungan Pengendalian Emosi dan penerimaan Teman Sebaya pada Remaja Awal. (skripsi tidak diterbitkan). Malang.

Suharsimi Arikunto. 2002. Prosedur Penelitian Suatu Pendekatan Praktek.(edisi revisi V, cetakan keduabelas). Jakarta: Rineka Cipta.

Sumadi Suryabrata. 1982. Psikologi Kepribadian. Jakarta: CV Rajawali.

Sumadi Suryabrata. 2002. Psikologi Kepribadian. Jakarta: Raja Grafindo Persada.

Sunarto dan Agung Hartono. 1994. Perkembangan Peserta Didik. Proyek Pembinaan dan Peningkatan Mutu Tenaga Kependidikan Direktorat Jendral Pendidikan Tinggi Departemen Pendidikan dan Kebudayaan.

Syamsu Yusuf. 2001. Psikologi Perkembangan Anak dan remaja. Bandung: PT Remaja Rosdakarya.

Tulus Winarsunu. 2002. Statistic dalam Penelitian Psikologi dan Pendidikan. Malang: UMM Press. 